\title{
Targeting AgRP neurons to maintain energy balance: lessons from animal models
}

4 Sebastián Zagmutt ${ }^{1}$, Paula Mera ${ }^{1}$, M Carmen Soler-Vázquez $^{1}$, Laura Herrero ${ }^{1,2}$, Dolors Serra ${ }^{1,2}$

5

$6 \quad{ }^{1}$ Department of Biochemistry and Physiology, School of Pharmacy and Food Sciences, Institut de

7 Biomedicina de la Universitat de Barcelona (IBUB), Universitat de Barcelona, E-08028 Barcelona,

8 Spain

$9{ }^{2}$ Centro de Investigación Biomédica en Red de Fisiopatología de la Obesidad y la Nutrición 10 (CIBEROBN), Instituto de Salud Carlos III, E-28029 Madrid, Spain

11

Corresponding author:

13 Email: dserra@ub.edu

14

15 
Keywords: Central nervous system, AgRP neurons, food intake, peripheral metabolism, behavior

\section{Running title}

Role of AgRP neurons in energy balance

\section{Document statistics}

Word count (excluding references):

Figures: 3

Tables: 1

References: 100

\section{Abbreviations:}

ARC, Arcuate nucleus; POMC, Proopiomelanocortin; GABA, $\gamma$-Aminobutyric acid, LHA, lateral hypothalamic nucleus; VHA, ventromedial nuclei; PVH paraventricular; PBN, parabrachial nuclei; MSH, Melanocyte-stimulating hormone; CART, amphetamine-stimulating hormone transcript; ChR, channelrhodopsin; DREADDs, designer receptor exclusively activated by designer drugs, CNO, clozapine; PI3K, Phosphoinositide 3-kinase; $\mathrm{PIP}_{3}$, phosphatidylinositol-3,4,5-triphosphate; FOXO1, forkhead box O1; BSX, Brain specific homeobox; BAT, brown adipose tissue; ICV, intracerebroventricular; FAs, Fatty acids; AMPK, AMP-activated protein kinase; ACC, acetyl-CoA carboxylase; CPT1, carnitine palmitoyltransferase 1; FAS, fatty acid synthase; MCD malonyl-CoA decarboxylase; SNS sympathetic nervous system; WAT, white adipose tissue; ATF4, activating transcription factor 4; UCP1, uncoupling protein 1. 


\section{Abstract} appetite and food addictions in obesity and other diseases.

The current obesity epidemic is a major worldwide health and economic burden. In the modern environment, an increase in the intake of high-fat and high-sugar foods plays a crucial role in the development of obesity by disrupting the mechanisms governing food intake and energy balance. Food intake and whole-body energy balance are regulated by the central nervous system through a sophisticated neuronal network located mostly in the hypothalamus. In particular, the hypothalamic arcuate nucleus (ARC) is a fundamental center that senses hormonal and nutrient-related signals informing about the energy state of the organism. The ARC contains two small, defined populations of neurons with opposite functions: anorexigenic proopiomelanocortin (POMC)-expressing neurons and orexigenic Agouti-related protein (AgRP)-expressing neurons. AgRP neurons, which also coproduce neuropeptide $\mathrm{Y}$ (NPY) and $\gamma$-Aminobutyric acid (GABA), are involved in an increase in hunger and a decrease in energy expenditure. In this review, we summarize the key findings from the most common animal models targeting AgRP neurons and the tools used to discern the role of this specific neuronal population in the control of peripheral metabolism, appetite, feeding-related behavior, and other complex behaviors. We also discuss how knowledge gained from these studies has revealed new pathways and key proteins that could be potential therapeutic targets to reduce 


\section{Contents}

56 1. Introduction

57 2. Animal models targeting the activity of AgRP neurons

58 3. AgRP neurons regulate peripheral metabolism

59 3.1. AgRP neurons and glucose metabolism

60 3.2. AgRP neurons and lipid metabolism

61 3.3. The role of AgRP neurons in thermogenesis

62 4. The role of AgRP neurons in food intake

63 5. AgRP neurons regulate complex behaviors beyond feeding

64 6. Pharmacological modulation of AgRP neurons

65 7. Conclusions and future perspectives

66

67

Disclosure statement

68

Funding

References

69 Figure legends and table 


\section{Introduction}

The hypothalamus is a region of the diencephalon located below the thalamus on each side of the third ventricle. It is composed of many small neuronal nuclei that integrate endocrine, nutritional and sensory signals, which culminate in the generation of precise neuroendocrine, behavioral, and autonomic responses aimed at controlling body homeostasis. Anatomically, the hypothalamus extends from the anterior commissure, lamina terminalis, and optic chiasm to the caudal limit of the mammillary bodies. Within these anatomical limits, hypothalamic nuclei are organized into the following zones and regions: preoptic area, composed of the medial and lateral preoptic nuclei; lateral zone, includes the lateral hypothalamic nucleus (LHA), and the tuberal nuclei; and the medial zone, subdivided into the anterior (or supraoptic) region, which contains supraoptic, paraventricular (PVH), suprachiasmatic, and anterior nuclei; the tuberal region, which contains ventromedial nuclei (VHM), the dorsomedial hypothalamic nucleus, and the arcuate nucleus (ARC); and finally the third region or mammillary part, which consists of the medial, intermediate, and lateral mammillary and posterior hypothalamic nuclei.

The first experiments connecting the hypothalamus with the regulation of energy balance and food intake were done by Hetherington and Ranson over 70 years ago. Their studies reported that lesions in the VHM nuclei of rats caused hyperphagia and obesity [1]. Later, Anand and Brobeck demonstrated in 1951 that bilateral destruction of the lateral portion of the LHA causes complete inhibition of food intake [2]. These results gave rise to the "dual-center hypothesis", which suggests that VHM and LHA are the hypothalamic centers that regulate satiety and appetite respectively [3]. Nonetheless, following studies have further established that ARC nuclei play a more crucial role in the regulation of food intake and energy balance. 
The relevance of the ARC was identified with the discovery of the melanocortin system, which plays a key role in a number of homeostatic processes [4,5], and reviewed elsewhere [6,7] The melanocortin system consists of 1) melanocortin peptides ( $\alpha-, \beta$-, and $\gamma$-melanocyte-stimulating hormone (MSH) and adrenocorticotropic hormone) derived from the precursor proopiomelanocortin (POMC); 2) five melanocortin receptors (MCRs, MC1R-MC5R, MC3R and MC4R are particularly involved in food intake energy balance regulation), which are widely expressed in the hypothalamus; and 3) the endogenous melanocortin antagonist (AgRP). All these components are expressed mainly in two populations of hypothalamic neurons: neurons that co-produce AgRP, NPY, and GABA (AgRP/NPY neurons) $[8,9]$ and neurons that co-produce POMC and cocaine and amphetaminestimulating hormone transcript (CART) (POMC/CART neurons) [10] Both are located at the base of the hypothalamus in close proximity to fenestrated capillaries. POMC/CART neurons and AgRP/NPY neurons exert opposite functions and are reciprocally regulated (Fig.1). While POMC/CART neurons express anorexigenic peptides and have appetite-suppressing functions, AgRP/NPY neurons express orexigenic peptides and have an appetite-stimulating role. NPY acts as a neurotransmitter in the brain and is thought to have several functions besides food intake, including regulation of fat storage [11]. The appetite-stimulating response to NPY is mediated by multiple NPY receptor subtypes, which are all Gi protein-coupled receptors. There are six identified NPY receptors, but the Y1 and Y5 isoforms are most strongly associated with the effect of NPY on feeding revised in [12]. Furthermore, AgRP/NPY neurons also release AgRP neuropeptide, a melanocortin antagonist that prevents the binding of $\alpha-\mathrm{MSH}$ onto MC3R and MC4R, thus activating hunger [13]. AgRP/NPY neurons also release GABA. GABA is an inhibitory neurotransmitter, and may exert its orexigenic action through GABAergic-mediated inhibition of POMC/CART neurons [14]. 
In recent decades, many animal models have been used to establish the relevance of this system in food intake and energy balance regulation. In this review, we analyze the techniques and approaches used to generate these animal models and their contribution to dissecting the molecular mechanisms and specific roles of AgRP/NPY neurons (thereafter AgRP neurons) on the modulation of peripheral glucose and lipid metabolism, thermogenesis, food intake, feeding behaviors, and other complex behaviors beyond feeding. We believe that this comprehensive review will help researchers in the field in search of specific pharmacological strategies to fight against excessive eating, obesity,

121 and derived diseases.

\section{Animal models targeting the activity of AgRP neurons}

One of the oldest genetic models that demonstrated the involvement of the agouti protein in energy balance regulation is the lethal yellow $\mathrm{A}^{\mathrm{y}}$ mouse, which expresses the agouti protein in all tissues [15]. This mouse develops an obesogenic phenotype characterized by excessive food intake, hyperinsulinemia, and increased body weight. The study of $\mathrm{A}^{\mathrm{y}}$ mice also showed that the agouti protein acts as an antagonist at MC1R and MC4R.. Subsequently, using knock-out techniques, the genetic deletion of MC4R (MC4R-KO) further contributed to the understanding of the melanocortin system and its role in energy homeostasis. MC4R-KO mice also display hyperphagia and obesity under free-feeding conditions [16,17]. Despite this, AgRP-deficient mice show normal food intake,

132 body weight, and energy expenditure, and only a significant impairment in the regulation of body 133 weight during aging [18]. Furthermore using the Cre-loxP system, a large number of genes have been

134 deleted from AgRP neurons in an effort to dissect the molecular mechanisms involved in the main 135 physiological roles of this set of neurons $[14,19,20]$. Taken together, these studies suggested that the 
various components of the melanocortin system and specific AgRP genes might contribute differently to the regulation of food intake and energy balance, and thus motivated additional studies in the field. In recent years, several biotechnological tools have been developed and applied to study the physiological role of AgRP neurons. The optogenetic approach combines genetic and optical methods to control and monitor the activity of single neurons in living tissues [21,22]. This groundbreaking technique is based on the expression of microbial opsins, such as channelrhodopsin (ChR) or halorhodopsin, which are light-gated proteins that directly regulate the flow of ions across the plasma membrane. Thus, in mice expressing opsins, light stimulation might inhibit or stimulate the activity of specific neuronal populations. The analogous pharmacosynthetic chemogenetic approach, known as the designer receptor exclusively activated by designer drugs (DREADDs), has also been used to control the activity of a single neuronal population in mice. The DREADDs system is based on the expression of a synthetic G-protein coupled receptor that responds to an exogenous inert ligand such as Clozapine-N-oxide (CNO, inert ligand). Indeed, DREADD technology has been widely used to control the activity of AgRP neurons by delivering CNO to the experimental animals [23,24].

While these techniques have exposed the physiological functions of AgRP neurons, the undeniable demonstration of their critical role in the control of energy balance came from the study of AgRP neuron-ablated mice. This model was engineered to express the diphtheria toxin receptor (DTR) specifically in AgRP neurons (AgRP $\left.{ }^{\mathrm{DTR}}\right)$, which caused the selective ablation of these neurons upon delivery of diphtheria toxin $[25,26]$.

Altogether, the results obtained using the above approaches have identified AgRP neurons as a key hypothalamic neuronal population that not only modulates food intake and feeding-related behaviors, but also whole-body energy homeostasis, through the control of peripheral glucose and lipid metabolism and thermogenesis. 


\section{AgRP neurons regulate peripheral metabolism}

161

162

163

\subsection{AgRP neurons and glucose metabolism}

Every organism needs to match energy intake and expenditure to be able to subsist. Therefore, from a homeostatic perspective, hunger must be understood as a response emitted from the central nervous system in response to whole-body energy balance. For example, Horowitz $\mathrm{M}$ and colleagues showed in 1998 that physiological changes in blood glucose levels affect appetite [27]. Indeed, several decades ago, it had already been demonstrated that specific hypothalamic neurons can sense blood glucose concentrations. Yet, the precise molecular mechanisms underlying this observation are still incomplete.

Activation of AgRP neurons promotes food seeking and intake. After a meal, blood glucose levels increase and, as a result, POMC neurons are activated. While the mechanisms underlying the excitatory actions of glucose on anorexigenic POMC neurons are clear, it is not completely understood yet if and how glucose could directly inhibit AgRP activity, as revised [28,29].

Neurons could sense glucose levels through the ATP-dependent potassium (KATP) channels, which control potassium flow to depolarize or hyperpolarize the neuron membrane depending on the levels of ATP generated from glucose catabolism [28,30] (Fig. 2). The extracellular concentration of glucose in the brain is approximately $2.5 \mathrm{mM}$ during the fed state and $0.5-0.2 \mathrm{mM}$ during the fasted or hypoglycemic condition. POMC neurons increase spike firing when the concentration of brain glucose changes from $0.1 \mathrm{mM}$ to $2 \mathrm{mM}$ [31], and that is dependent on KATP channel subunits [32]. Conversely, the expression of a mutated $\mathrm{K}_{\text {ATP }}$ channel subunit that was insensitive to the ATP in POMC neurons impaired the whole-body response to a systemic glucose load [30]. 
It is unclear whether $K_{A T P}$ channels are also involved in the glucose-dependent modulation of AgRP neurons. Even though $K_{A T P}$ channels are expressed in AgRP neurons, probably because some of these neurons share a common progenitor with POMC neurons, only a minority of AgRP neurons are glucose responsive $[29,31,33,34]$. Yet, AgRP neurons respond to insulin levels. Insulin hyperpolarizes AgRP neurons in wild-type mice but not in those lacking the insulin receptor in AgRP neurons specifically (IR $\left.{ }^{\triangle A g R P}\right)$ [35]. Insulin inhibits AgRP neuronal activity by activating the phosphoinositide 3-kinase (PI3K) signaling pathway. The phosphatidylinositol3,4,5-triphosphate $\left(\mathrm{PIP}_{3}\right)$ that is generated activates KATP channels, resulting in hyperpolarization and a decreased neuronal firing rate, with subsequent reduced release of AgRP [35]. PI3K activation ultimately leads to the exclusion of forkhead box O1 (FOXO1) transcription factor from the nucleus [36]. FOXO1 increases AgRP expression [37], thus insulin action in AgRP neurons ultimately decreases the expression of AgRP. This signaling pathway has also been described in POMC neurons, but in those neurons the exclusion of FOXO1 from the nucleus promotes POMC expression [38]. Taken together, these studies suggest that POMC neurons sense glucose levels, while AgRP neurons respond to changes in insulin concentration. In addition, AgRP neurons influence peripheral glucose metabolism. For instance, the ablation

197 of these neurons in adult $\mathrm{AgRP}^{\mathrm{DTR}}$ mice caused a reduction in blood glucose levels 48 hours after the 198 administration of diphtheria toxin [39]. One of the molecular explanations for this phenotype is the 199 decreased hepatic gluconeogenesis observed in this model [35,40]. Accordingly, the acute activation 200 of AgRP neurons using either a chemogenetic or optogenetic approach caused an increase in blood 201 glucose levels due to systemic insulin resistance and decreased glucose uptake in brown adipose tissue 202 (BAT) [24]. At molecular level, several genes in AgRP neurons have been associated with this regulation of whole-body glucose homeostasis. For instance, the deletion of purinergic receptor 6 
(P2Y6) specifically in AgRP neurons, improved systemic insulin sensitivity in obese mice [41] and similar results have been observed when the transcription factor activating transcription factor 4 (ATF4) was deleted specifically in AgRP neurons [42].

\subsection{AgRP neurons and lipid metabolism}

Fatty acids (FAs) are the primary fuel for most tissues under the fasting state. Therefore, FA levels are associated with the energy status of the organism. Importantly, FAs can cross the bloodbrain barrier and be oxidized in the brain. These observations raise the question of whether FAs could be a signal to AgRP neurons. It has been shown that intracerebroventricular (icv) administration of long-chain FAs inhibits the expression of NPY and AgRP in the hypothalamus, and therefore food intake [43]. Very recently, it has been reported that GPR120 and GPR40, also known as Free fatty acid receptor 1, are expressed in the hypothalamus of mice. The majority of cells that express POMC and AgRP also express GPR40 [44]. This receptor binds free FAs, acting as a nutrient sensor [44,45]. Of note, the icv administration of TUG905, which is an agonist of GPR40, reduces body weight [44]. The fact that GPR40 is expressed in AgRP and POMC neurons suggests that these cells could sense the content of FAs in the hypothalamus to regulate food intake and peripheral energy metabolism accordingly.

Besides, most enzymes of the FA metabolic pathways are expressed in the hypothalamus, including AMP-activated protein kinase (AMPK) [46,47], acetyl-CoA carboxylase (ACC), carnitine palmitoyltransferase 1 (CPT1), fatty acid synthase (FAS), and malonyl-CoA decarboxylase (MCD) [48]. Of note, fasting stimulates hypothalamic AMPK and inhibits ACC and FAS activities, whereas re-feeding induces opposite changes $[49,50]$. Moreover, pharmacological and genetic manipulation of some of these genes/proteins has a profound impact on food intake and whole-body energy 
homeostasis. For instance, icv administration of the FAS inhibitor cerulenin reduces feeding and causes weight loss due to the reduction of NPY and AgRP expression in the hypothalamus [51]. The anorectic effect of this drug requires the accumulation of malonyl-CoA in the hypothalamus, which in turn inhibits CPT1A, a key regulatory enzyme of the FA oxidation pathway. In agreement with these observations, the long-term increase of FA oxidation in the ventromedial hypothalamus, through the expression of a mutated and permanently active form of CPT1A, caused hyperphagia and increased body weight in rats [52]. Future studies are needed to elucidate whether enzymes from the FA metabolism pathway in specific ARC neuronal populations, i.e. AgRP or POMC neurons, play a role in the regulation of food intake and peripheral energy metabolism. Additionally, the hypothalamus regulates peripheral lipid metabolism and adiposity. For instance, disruption of melanocortin signaling in the brain promotes lipid uptake, triglyceride synthesis, and fat accumulation in white adipose tissue (WAT) [53]. Conversely, stimulation of MCRs reduces adiposity [54]. Within the hypothalamus, the activity of AgRP neurons impacts peripheral lipid metabolism. In fact, the activation of AgRP neurons promotes lipogenesis via the sympathetic nervous system (SNS) [55]. Additionally, the deletion of carnitine acyltransferase specifically in AgRP neurons increased FA utilization and attenuated the switch to glucose utilization after refeeding [56]. Moreover, the deletion of ATF4 specifically in AgRP neurons increases lipolysis in

244 epididymal WAT, thus promoting fat loss [42]. Taken together, these results indicate that targeting 245 the activity of AgRP neurons might be a good strategy to reduce adiposity in certain pathological 246 conditions characterized by excessive fat accumulation, such as obesity. 

Rothwell A and Stock M in 1997. The study demonstrated that food consumption increases the activity of BAT through the SNS, which could be an important compensatory mechanism in case of energy surplus [57]. In addition, caloric restriction and feeding-fasting cycles also regulate body temperature and thermogenesis in BAT [58]. While it is known that sympathetic activity in BAT and WAT controls heat production and energy homeostasis [59], the same neurons that regulate energy intake may also control feeding-induced thermogenesis.

Adipose tissue can be classified as WAT, which stores energy in the form of triglycerides, and BAT, which is highly oxidative and contains abundant mitochondria that oxidize FAs to generate heat via the BAT specific uncoupling protein 1 (UCP1). In response to specific stimuli, certain WAT depots can undergo a process known as browning where the tissue takes on characteristics of BAT, 260 including the expression of UCP1. The icv infusion of AgRP gradually suppressed sympathetic tone 261 in BAT thus decreasing thermogenesis [60]. Using the optogenetic approach, acute activation of AgRP neurons strongly inhibited the expression of thermogenic genes, including Ucp1, in retroperitoneal WAT, and to a lesser extent in inguinal WAT, which indicates that AgRP neurons suppress the browning of WAT [61]. While the inhibition of AgRP neuronal activity by selectively deleting the O-GlcNAc transferase caused WAT browning in those mutant mice [61] through its receptor (GHS-R) to activate food consumption. Deletion of GHS-R specifically in AgRP neurons (AgRP-Cre;Ghsrfff mice) caused increased energy expenditure in mice fed a HFD, and 269 enhanced thermogenic activation in both BAT and subcutaneous WAT [62]. Overall, the role of 270 AgRP neurons in thermogenesis could be an important target to increase energy expenditure and thus 271 fight against obesity. 


\section{The role of AgRP neurons in food intake}

There are numerous neurons distributed in the brain that influence appetite [63], yet AgRP neurons within the hypothalamus are probably the neuronal population that has the strongest and most closely documented association with feeding behavior $[64,65]$. The first evidence supporting the role of AgRP neurons in food intake control came from experiments showing that AgRP and NPY injection in the brain increase food intake. It was also drawn from the observation the AgRP and NPY release is higher in brain sections of food-deprived mice [66,67].

These early results have been confirmed recently by using the innovative cell type-specific approaches mentioned in Section 2 of this review. For example, optogenetic and pharmacogenetic activation of AgRP neurons result in a robust increase in food intake, even in fed mice $[68,69]$.

Moreover, ablation of AgRP neurons in adult, but not neonatal, mice results in an acute reduction of feeding and starvation $[25,26,70]$. The differences observed between neonatal and adult mice suggest that network-based compensatory mechanisms can occur in neonates but not in the adult stage [71]. Surprisingly, deletion of the entire Agrp coding sequence using BAC-based targeting vectors did not generate differences in food intake or body weight in adult mice before 6 months of age [38]. Likewise, deletion of Npy had little effect on body weight control [72,73]. These observations suggest that GABA, also produced by AgRP neurons, might be a critical neurotransmitter regulating food

290 intake and energy balance. Actually, disruption of GABA signaling by selective inactivation of the 291 vesicular GABA transporter gene (Vgat) in AgRP neurons caused a lean phenotype and protected 292 mice from diet-induced obesity [14]. Accordingly, chronic and subcutaneous delivery of bretazenil (a $293 \mathrm{GABA}_{\mathrm{A}}$ receptor partial agonist) prevented starvation in AgRP neuron-ablated mice [74]. 
GABA is an inhibitory neurotransmitter and thus GABAergic input from AgRP neurons inhibits the activity of several neuronal populations within the brain, including POMC neurons from the ARC. This crosstalk between orexigenic and anorexigenic neurons in the ARC is essential for the precise regulation of food intake [65]. In addition, GABAergic projections from AgRP neurons also suppress the activity of neurons in the PVH [75]. Because activation of PVH neurons decreases feeding [76], it has been suggested that AgRP neurons increase food intake in part through the GABAergic inhibition of PVH neurons. Another important GABAergic target of AgRP neurons is the parabrachial nuclei (PBN). However, in this nucleus the effect of GABA promotes feeding, since administration of bretazenil (a GABA(A) receptor partial agonist) into the PBN prevents starvation in AgRP neuron-ablated mice [74].

Independently of the neurotransmitter released, there are many areas in the brain under the control of AgRP neurons that regulate feeding behavior. Elegant optogenetic experiments by Brüning and colleagues confirmed previous studies showing that AgRP neurons control neurons in the PVH to influence feeding. Likewise, they showed that LHA and the anterior bed nucleus of the stria terminalis (aBNST) dorsomedial nucleus were activated by AgRP projections to promote feeding, while the dorsal vagal complex, dorsal raphe nucleus and aBNST ventral lateral nucleus were not [24]. Overall, this study suggested that AgRP neurons orchestrate the activation and inactivation of various brain areas to promote food seeking and intake.

Now the question is: what is the mechanism by which AgRP neurons are activated upon starvation? A large amount of evidence indicates that ghrelin action on these neurons leads to their

314 activation. Ghrelin is a 28 -amino acid peptide produced in the stomach. Ghrelin blood levels increase 315 preprandially and decrease postprandially. Ghrelin increases food intake by activating its receptor 316 GHS-R in AgRP neurons [77,78] (Fig .3). Of note, ghrelin administration increases AgRP firing in 
brain slices from control mice but not from mice lacking Ghsr specifically in AgRP neurons 318 (Ghsr $\left.{ }_{\mathrm{AgRP}}-/-\right)$ [79]. Ghrelin increases the mRNA levels of NPY and AgRP in AgRP neurons, yet the molecular mechanism remains partially unclear [80]. It has been suggested that the AMPK-CPT1A$\mathrm{UCP} 2$ axis is a relevant pathway in the ARC, which is involved in ghrelin's control of food intake [81]. AMPK is a downstream target of GHS-R, and upon its activation it inhibits ACC, thus decreasing the intracellular levels of malonyl-CoA. Malonyl-CoA is the physiological inhibitor of CPT1A, which is the rate-limiting step in the mitochondrial FA oxidation pathway. Increased FA oxidation generates reactive oxygen species (ROS) and subsequent uncoupling protein-2 (UCP2) activity. Using a mouse model lacking Ucp2 in all cells, it had been suggested that UCP2 mediates ghrelin's actions on AgRP neurons by lowering free radicals [82]. However, cell-type specific studies are needed to clarify the role of UCP2 in AgRP neurons in regulating food intake. Another proposed candidate to mediate ghrelin's orexigenic action in the ARC is the NAD+dependent class III deacetylases SIRT1. Sirt1 is expressed in the hypothalamus, its function is redox dependent, and it is induced by negative energy balance. In fact, central administration of ghrelin increases SIRT1 activity in the hypothalamus and blockade of SIRT1 abolished the orexigenic effect of this hormone [83]. Another study showed that the Sirtuin 1/p53 pathway is essential for the

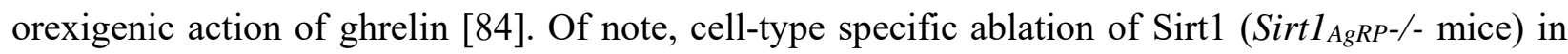
AgRP neurons determined that this neuronal population mediates the action of SIRT1 on energy balance: Sirt1AgRP-/- mice show decreased electric responses of AgRP neurons to ghrelin, decreased food intake, decreased lean mass, fat mass, and body weight [83].

Finally, ghrelin stimulates AgRP and NPY neuropeptide expression through the activation of transcriptional factors, such as Brain specific homeobox (BSX) protein. BSX needs to interact with another two transcription factors to activate Agrp and Npy mRNA expression: FOXO1 for the Agrp 
gene and the phosphorylated cAMP response-element-binding protein (pCREB) for the Npy gene

341 [85]. Yet, the activation of BSX downstream of the AMPK-ACC-CPT1A-UCP2 axis remains unclear.

342 Nonetheless, it has been demonstrated that FOXO formed a complex with SIRT1 in response to 343 oxidative stress [86] and enhances FOXO transcriptional activity [87], but so far there is no evidence 344 that all these events occur specifically in neuronal cells.

\section{AgRP neurons regulate complex behaviors beyond feeding}

As reviewed in the previous sections, hypothalamic neurons that co-produce NPY, AgRP, and GABA are fundamental in the regulation of food intake and peripheral metabolism. In addition, the study of animal models targeting the activity of AgRP neurons has revealed that these cell populations 350 also coordinate other complex behaviors beyond feeding. Mice with compromised AgRP neuronal 351 excitability (Sirt $1_{\mathrm{AgRP}-/-}$ mice) exhibit greater locomotor activity and exploratory behavior than control littermates during an open field test (OFT) [88]. The same is true in AgRP-neuron-ablated mice. Conversely, brain infusion of AgRP in rats reduces locomotor activity [89]. The OFT is an approach/avoidance assay based on the fact that a novel environment (an open field box) evokes both anxiety and exploration in the experimental animal [90]. Therefore, the increased exploratory 356 behavior observed in Sirt1 $1_{g R P}-/-$ and AgRP-neuron-ablated mice suggests that activity of AgRP

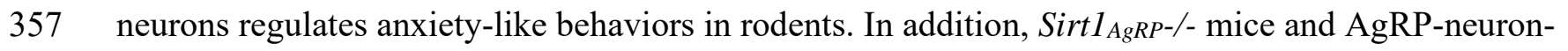
358 ablated mice show an increased response and preference for cocaine, suggesting that AgRP neurons 359 also affect reward circuits [88]. Exploring this possibility revealed that AgRP fibers innervate the 360 ventral tegmental area (VTA) in the midbrain, where dopaminergic neurons responsible for reward 361 seeking are located [88]. Intriguingly, the activation of AgRP neurons also decreases anxiety during 362 an OFT and an elevated plus-maze (EPM) test [91]. During an EPM test, anxiety-like behaviors 
inversely correlate with the time that animals spend in the open arms of an EPM apparatus comprised of two open and two enclosed arms elevated from the floor [92]. The fact that the activation and ablation of AgRP neurons causes an apparently similar decrease in anxiety-like behaviors requires further investigation. However, it also highlights the role of hypothalamic AgRP neurons in regulating complex behavior. Additionally, activation of hypothalamic AgRP neurons in the absence of food stimuli triggers foraging and other stereotypic behaviors [91]. Of note, some aspects of these stereotypic behaviors are not seen in food-deprived animals, which suggests that subpopulations of AgRP neurons have different functions. Altogether, these observations revealed a previously unsuspected role for hypothalamic AgRP neurons in controlling complex behaviors beyond feeding 372 in mice.

\section{Pharmacological modulation of AgRP neurons}

375 New insights into the neuronal circuit to control feeding behaviors and energy homeostasis are essential to devise specific pharmacological strategies that could be useful to treat obesity and its complications.

Many receptors expressed in AgRP neurons have been identified to understand which molecule could be useful for pharmacological manipulation (Table 1). A recent finding revealed that norepinephrine (NE) activates AgRP neurons due to $\alpha 1 \mathrm{~A}-\mathrm{Ars}$, which suggests an orexigenic influence of NE in ARC nuclei [93]. Furthermore, Uridine-diphosphate (UD) and its receptor P2Y6 have

382 recently been identified as regulators of AgRP neurons that promote feeding through the activation 383 of these neurons [41]. Interestingly, AgRP neurons express angiotensin $\mathrm{AT}_{1 \mathrm{~A}}$ receptor and the lack of 384 this receptor exhibits attenuated BAT sympathetic nerve activity in response to leptin, which suggests 385 that some $\mathrm{AT}_{1 \mathrm{~A}}$ agonists and antagonists could be useful to modulate energy expenditure [94]. Many 
of these receptors belong to the GPCR family receptors with distinct coupling G protein associated. It seems that Gs protein has a strong association with food intake because the activation of Gs-coupled receptor expressed by AgRP neurons leads to a robust increase in food intake [95]. Alternatively, key regulatory factors of AgRP activation such as Sirtl could be interesting targets to control food intake. It has been demonstrated that the Sirt1 inhibitor (EX-527) injected peripherally or icv decreased food intake during the dark cycle and ghrelin-induced food intake [83]. Altogether, this indicates that there is a need for further studies to discover new therapeutic targets and their efficient drugs.

However, the aforementioned receptors and ligands belong to a ubiquitous system and therefore new approaches are necessary to target exclusively specific neuronal populations, such as AgRP. One possibility is the use of chemogenetic tools. Usually, these technologies involve genetically targeting the sensitivity to an otherwise inert small ligand. For example, the group of Sternson has developed chemogenetic technologies (such as the pharmacologically selective actuator modules/pharmacologically selective effector molecule - PSAM/PSEM) that could be applied in conjunction with gene therapies in humans to target specific cell populations. Noteworthy, PSAM/PSEM has been already used in mice to silence specifically AgRP neurons, which resulted in a suppression of food intake and learning enhancement [96]. In addition, chemogenetic approaches have been used in mice to induce dimerization of proteins, destabilization of domains or inhibition of engineered kinases in a cell-specific manner [97].

Alternatively, enormous research efforts have been focused on brain drug delivery to develop new therapies for brain disease. Recent studies have analysed new tools to enhance the delivery of drugs across the blood brain barrier and drug uptake by neurons. Some of these tools include nanocarriers that transport bioactive substances to a target site [98]. Unfortunately, currently none of these strategies has accomplished a cell-specific drug 
delivery. Nonetheless, these technologies provide an exciting prospect for the future development of human therapies.

\section{Conclusions and future directions}

413 The mouse genetic revolution has shown repeatedly that hypothalamic neurons are crucial in the

414 regulation of appetite and whole-body energy balance. In particular, data from all these animal studies

415 have highlighted AgRP and POMC neurons as key components of the neuronal circuits that control 416 food intake and peripheral energy metabolism. In this review, we have focused deliberately on AgRP 417 neurons because of the vast number of animal models targeting this specific neuronal population. In 418 summary, all these in vivo studies have established that AgRP neurons integrate interoceptive, 419 nutritional, endocrine, and sensory information to coordinate goal-directed behavior, such as food 420 seeking and intake. Thus, activation of AgRP neurons stimulates feeding as well as a rapid decrease 421 in energy expenditure. At the molecular level, several genes and proteins have been identified as potential players controlling AgRP neuronal function. These include receptors for hormones, such as insulin and ghrelin, enzymes of the FA metabolism pathway, SIRT1, and transcription factors such as ATF4. Of note, many of these molecules might be potential targets in the treatment of eating disorders, i.e. anorexia nervosa or compulsive eating, and metabolic diseases such as obesity. Moving forward, it remains crucial to question whether differences in AgRP neuronal function exist

427 between individuals vulnerable or invulnerable to developing disorders characterized by dysregulated 428 energy balance. Moreover, future studies are needed to determine whether specific subpopulations of 429 AgRP neurons are responsible for the regulation of food intake and other aspects of energy 430 homeostasis. Lastly, considering the heterogeneity of the hypothalamus and the opposite functions of 431 different hypothalamic neuronal populations, we believe that future efforts must be focused on 
432 developing cell-type specific drug delivery methods, in order to design efficient and safe treatments 433 for eating disorders, obesity, and related pathologies.

434

\section{Disclosure statement}

436 The authors declare no conflicts of interest.

\section{Funding}

439 This work was supported by the Ministry of Spain (MINECO) (Grant SAF2017-83813-C3-1-R to DS 440 and LH cofunded by the European Regional Development Fund [ERDF]), the Centro de Investigación 441 Biomédica en Red de Fisiopatología de la Obesidad y la Nutrición (CIBEROBN) (Grant 442 CB06/03/0001 to DS), and the Fundació La Marató de TV3 (Grant 87/C/2016 to DS). MCS-V is a 443 recipient of the Ajut de Personal Investigador Predoctoral en Formació (APIF) fellowship from the 444 University of Barcelona, SZ of the Comisión Nacional de Investigación Científica y Tecnológica 445 (CONICYT) fellowship from Chile, and PM of the Juan de la Cierva-Incorporación fellowship from 446 MINECO. 
452 [1] A.W. Hetherington, S.W. Ranson, The relation of various hypothalamic lesions to adiposity in the rat, J. Comp. Neurol. 76 (1942) 475-499. doi:10.1002/cne.900760308.

454 [2] B.K. Anand, J.R. Brobeck, Hypothalamic control of food intake in rats and cats., Yale J. Biol. Med. 24 (1951) 123-40.

[3] J.K. Elmquist, C.F. Elias, C.B. Saper, From lesions to leptin: hypothalamic control of food

[4] P.S. Singru, E. Sánchez, C. Fekete, R.M. Lechan, Importance of melanocortin signaling in refeeding-induced neuronal activation and satiety, Endocrinology. 148 (2007) 638-646. doi:10.1210/en.2006-1233.

[5] A.A. Van Der Klaauw, J.M. Keogh, E. Henning, C. Stephenson, S. Kelway, V.M. Trowse, N. Subramanian, S. O’Rahilly, P.C. Fletcher, I.S. Farooqi, Divergent effects of central melanocortin signalling on fat and sucrose preference in humans, Nat. Commun. 7 (2016) 15. doi:10.1038/ncomms13055.

[6] K.G. Mountjoy, Pro-Opiomelanocortin (POMC) Neurones, POMC-Derived Peptides, Melanocortin Receptors and Obesity: How Understanding of this System has Changed Over the Last Decade, J. Neuroendocrinol. 27 (2015) 406-418. doi:10.1111/jne.12285.

[7] E.J.P. Anderson, I. Cakir, S.J. Carrington, R.D. Cone, M. Ghamari-Langroudi, T. Gillyard, L.E. Gimenez, M.J. Litt, Regulation of feeding and energy homeostasis by $\alpha$-MSH, J. Mol. Endocrinol. 56 (2016) T157-T174. doi:10.1530/JME-16-0014.

[8] G.S. Kelly J, GABA and hypothalamic feeding systems. II. A comparison of GABA, glycine and actylcholine agonists and their antagonists.Pharmacol Biochem Behav, Pharmacol 
Biochem Behav. 11 (1979) 647-52.

474 [9] S.P.K. John T. Clark, Pushpa S. Kalra, William R. Crowley, Neuropeptide Y and human pancreatic polypeptide stimulate feeding behavior in rats, Endocrinology. 115 (1984) 427429. doi:org/10.1210/endo-115-1-427.

[10] J. Douglass, a a McKinzie, P. Couceyro, PCR differential display identifies a rat brain mRNA that is transcriptionally regulated by cocaine and amphetamine., J. Neurosci. 15 (1995) 2471-2481.

[11] K. Yang, H. Guan, E. Arany, D.J. Hill, X. Cao, Neuropeptide Y is produced in visceral adipose tissue and promotes proliferation of adipocyte precursor cells via the Y1 receptor, FASEB J. 22 (2008) 2452-2464. doi:10.1096/fj.07-100735.

[12] C.W. Shaun P. Brothers, Therapeutic potential of neuropeptide Y (NPY) receptor ligands, EMBO Mol. Med. 2 (2010) 429-439. doi:10.1002/emmm.201000100.

[13] Y. Chen, Z.A. Knight, Making sense of the sensory regulation of hunger neurons, BioEssays. 38 (2016) 316-324. doi:10.1002/bies.201500167.

[14] Q. Tong, C.-P. Ye, J.E. Jones, J.K. Elmquist, B.B. Lowell, Synaptic release of GABA by AgRP neurons is required for normal regulation of energy balance, Nat. Neurosci. 11 (2008) 998. doi:org/10.1038/nn.2167.

[15] Margaret M. Dickies, A new viable yellow mutation in the house mouse, J. Hered. 53 (1962) 84-86. doi:org/10.1093/oxfordjournals.jhered.a107129.

[16] D.C. Albarado, J. McClaine, J.M. Stephens, R.L. Mynatt, J. Ye, A.W. Bannon, W.G. Richards, A.A. Butler, Impaired coordination of nutrient intake and substrate oxidation in melanocortin-4 receptor knockout mice, Endocrinology. 145 (2004) 243-252. doi:10.1210/en.2003-0452. 
[17] D. Huszar, C.A. Lynch, V. Fairchild-Huntress, J.H. Dunmore, Q. Fang, L.R. Berkemeier, W. Gu, R.A. Kesterson, B.A. Boston, R.D. Cone, F.J. Smith, L.A. Campfield, P. Burn, F. Lee, Targeted Disruption of the Melanocortin-4 Receptor Results in Obesity in Mice, Cell. 88 (1997) 131-141. doi:10.1016/S0092-8674(00)81865-6.

[18] K.E. Wortley, K.D. Anderson, J. Yasenchak, A. Murphy, D. Valenzuela, S. Diano, G.D. Yancopoulos, S.J. Wiegand, M.W. Sleeman, Agouti-related protein-deficient mice display an age-related lean phenotype, Cell Metab. 2 (2005) 421-427. doi:10.1016/j.cmet.2005.11.004.

[19] Y. He, G. Shu, Y. Yang, P. Xu, Y. Xia, C. Wang, K. Saito, A. Hinton, X. Yan, C. Liu, Q. Wu, Q. Tong, Y. Xu, A Small Potassium Current in AgRP/NPY Neurons Regulates Feeding Behavior and Energy Metabolism, Cell Rep. 17 (2016) 1807-1818. doi:10.1016/j.celrep.2016.10.044.

[20] A. Üner, G.H.M. Gonçalves, W. Li, M. Porceban, N. Caron, M. Schönke, E. Delpire, K. Sakimura, C. Bjørbæk, The role of GluN2A and GluN2B NMDA receptor subunits in AgRP and POMC neurons on body weight and glucose homeostasis, Mol. Metab. 4 (2015) 678691. doi:10.1016/j.molmet.2015.06.010.

[21] L. Fenno, O. Yizhar, K. Deisseroth, The Development and Application of Optogenetics, Annu. Rev. Neurosci. 34 (2011) 389-412. doi:10.1146/annurev-neuro-061010-113817.

[22] K. Deisseroth, Optogenetics: 10 years of microbial opsins in neuroscience, Nat. Neurosci. 18 (2015) 1213. http://dx.doi.org/10.1038/nn.4091.

[23] M.J. Krashes, S. Koda, C. Ye, S.C. Rogan, A.C. Adams, D.S. Cusher, E. Maratos-Flier, B.L. Roth, B.B. Lowell, Rapid, reversible activation of AgRP neurons drdives feeding behavior in mice, J. Clin. Invest. 121 (2011) 1424-28. doi:10.1172/JCI46229DS1.

[24] S.M. Steculorum, J. Ruud, I. Karakasilioti, H. Backes, L.E. Ruud, K. Timper, M.E. Hess, E. 
Tsaousidou, J. Mauer, M.C. Vogt, L. Paeger, S. Bremser, A.C. Klein, D.A. Morgan, P. Frommolt, P.T. Brinkkötter, P. Hammerschmidt, T. Benzing, K. Rahmouni, F.T. Wunderlich, P. Kloppenburg, J.C. Brüning, HHS Public Access, 165 (2016) 125-138. doi:10.1016/j.cell.2016.02.044.AgRP.

[25] Q. Wu, M.P. Howell, M.A. Cowley, R.D. Palmiter, Starvation after AgRP neuron ablation is independent of melanocortin signaling, Proc. Natl. Acad. Sci. 105 (2008) 2687-2692. doi:10.1073/pnas.0712062105.

[26] M. Saito, T. Iwawaki, C. Taya, H. Yonekawa, M. Noda, Y. Inui, E. Mekada, Y. Kimata, A. Tsuru, K. Kohno, Diphtheria toxin receptor-mediated conditional and targeted cell ablation in transgenic mice, Nat. Biotechnol. 19 (2001) 746. doi:org/10.1038/90795.

[27] A.J. Physiol, R. Integr, C. Physiol, I.M. Chapman, E.A. Goble, G.A. Wittert, J.E. Morley, K. Beckoff, C.G. Macintosh, J.M. Wishart, A. Howard, M. Horowitz, K.L. Jones, G. Liver, I.A.N.M. Chapman, M. Ian, G.A. Wit-, Effect of intravenous glucose and euglycemic insulin infusions on short-term appetite and food intake appetite in the elderly, (1998) 596-603.

[29] B.F. Belgardt, T. Okamura, J.C. Brüning, Hormone and glucose signalling in POMC and AgRP neurons, J. Physiol. 587 (2009) 5305-5314. doi:10.1113/jphysiol.2009.179192.

[30] L.E. Parton, C.P. Ye, R. Coppari, P.J. Enriori, B. Choi, C.-Y. Zhang, C. Xu, C.R. Vianna, N. Balthasar, C.E. Lee, J.K. Elmquist, M.A. Cowley, B.B. Lowell, Glucose sensing by POMC neurons regulates glucose homeostasis and is impaired in obesity, Nature. 449 (2007) 228. doi:org/10.1038/nature06098. 

doi:10.1172/JCI31516.suming.

[32] N. Ibrahim, M.A. Bosch, J.L. Smart, J. Qiu, M. Rubinstein, O.K. Rønnekleiv, M.J. Low, M.J. Kelly, Hypothalamic proopiomelanocortin neurons are glucose responsive and express

[35] A.C. Könner, R. Janoschek, L. Plum, S.D. Jordan, E. Rother, X. Ma, C. Xu, P. Enriori, B. Hampel, G.S. Barsh, C.R. Kahn, M.A. Cowley, F.M. Ashcroft, J.C. Brüning, Insulin Action in AgRP-Expressing Neurons Is Required for Suppression of Hepatic Glucose Production, Cell Metab. 5 (2007) 438-449. doi:10.1016/j.cmet.2007.05.004.

[36] T. Kitamura, Y. Feng, Y. Ido Kitamura, S.C. Chua Jr, A.W. Xu, G.S. Barsh, L. Rossetti, D. Accili, Forkhead protein FoxO1 mediates Agrp-dependent effects of leptin on food intake, Nat. Med. 12 (2006) 534. doi:org/10.1038/nm1392.

[37] L. Varela, M.J. Vázquez, F. Cordido, R. Nogueiras, A. Vidal-Puig, C. Diéguez, M. López, Ghrelin and lipid metabolism: Key partners in energy balance, J. Mol. Endocrinol. 46 (2011) 43-63. doi:10.1677/JME-10-0068. 
[38] W. Ma, G. Fuentes, X. Shi, C. Verma, G.K. Radda, W. Han, FoxO1 negatively regulates leptin-induced POMC transcription through its direct interaction with STAT3, Biochem. J. 466 (2015) 291 LP-298. doi:10.1042/BJ20141109.

[39] E. Gropp, M. Shanabrough, E. Borok, A.W. Xu, R. Janoschek, T. Buch, L. Plum, N. Balthasar, B. Hampel, A. Waisman, G.S. Barsh, T.L. Horvath, J.C. Brüning, Agouti-related peptide-expressing neurons are mandatory for feeding, Nat. Neurosci. 8 (2005) 1289-1291. doi:10.1038/nn1548.

[40] H. Inoue, W. Ogawa, A. Asakawa, Y. Okamoto, A. Nishizawa, M. Matsumoto, K. Teshigawara, Y. Matsuki, E. Watanabe, R. Hiramatsu, K. Notohara, K. Katayose, H. Okamura, C.R. Kahn, T. Noda, K. Takeda, S. Akira, A. Inui, M. Kasuga, Role of hepatic STAT3 in brain-insulin action on hepatic glucose production, Cell Metab. 3 (2006) 267-275. doi:10.1016/j.cmet.2006.02.009.

[41] S.M. Steculorum, K. Timper, L. Engström Ruud, N. Evers, L. Paeger, S. Bremser, P. Kloppenburg, J.C. Brüning, Inhibition of P2Y6 Signaling in AgRP Neurons Reduces Food Intake and Improves Systemic Insulin Sensitivity in Obesity, Cell Rep. 18 (2017) 1587-1597. doi:10.1016/j.celrep.2017.01.047.

[42] J. Deng, F. Yuan, Y. Guo, Y. Xiao, Y. Niu, Y. Deng, X. Han, Y. Guan, S. Chen, F. Guo, Deletion of ATF4 in AgRP neurons promotes fat loss mainly via increasing energy expenditure, Diabetes. 66 (2017) 640-650. doi:10.2337/db16-0954.

[43] S. Obici, Z. Feng, K. Morgan, D. Stein, G. Karkanias, L. Rossetti, Central Administration of Oleic Acid Inhibits Glucose Production and Food Intake, Diabetes. 51 (2002) 271 LP-275. doi:org/10.2337/diabetes.51.2.2.271.

[44] N.R.V. Dragano, C. Solon, A.F. Ramalho, R.F. de Moura, D.S. Razolli, E. Christiansen, C. 
Azevedo, T. Ulven, L.A. Velloso, Polyunsaturated fatty acid receptors, GPR40 and GPR120, are expressed in the hypothalamus and control energy homeostasis and inflammation, J. Neuroinflammation. 14 (2017) 1-16. doi:10.1186/s12974-017-0869-7.

[45] C.F. Burant, Activation of GPR40 as a therapeutic target for the treatment of type 2 diabetes, Diabetes Care. 36 (2013) 175-179. doi:10.2337/dcS13-2037.

593

[46] M. López, R. Nogueiras, M. Tena-Sempere, C. Diéguez, Hypothalamic AMPK: a canonical regulator of whole-body energy balance, Nat. Rev. Endocrinol. 12 (2016) 421. doi:org/10.1038/nrendo.2016.67.

[47] M.K.Q. Huynh, A.W. Kinyua, D.J. Yang, K.W. Kim, Hypothalamic AMPK as a Regulator of Energy Homeostasis, Neural Plast. 2016 (2016). doi:10.1155/2016/2754078.

[48] Z.J. JulianSwierczynski, Elzbieta Goykea, Justyna Korczynska, Acetyl-CoA carboxylase and fatty acid synthase activities in human hypothalamus, Neurosci. Lett. 444 (2008) 209-211. doi:10.1016/jneulet.2008.08.046.

[49] M. López, R. Lage, A.K. Saha, D. Pérez-Tilve, M.J. Vázquez, L. Varela, S. SangiaoAlvarellos, S. Tovar, K. Raghay, S. Rodríguez-Cuenca, R.M. Deoliveira, T. Castañeda, R. Datta, J.Z. Dong, M. Culler, M.W. Sleeman, C. V Álvarez, R. Gallego, C.J. Lelliott, D. Carling, M.H. Tschöp, C. Diéguez, A. Vidal-Puig, Hypothalamic Fatty Acid Metabolism Mediates the Orexigenic Action of Ghrelin, Cell Metab. 7 (2008) 389-399. doi:10.1016/j.cmet.2008.03.006.

[50] Y. Minokoshi, T. Alquier, N. Furukawa, Y.-B. Kim, A. Lee, B. Xue, J. Mu, F. Foufelle, P. Ferré, M.J. Birnbaum, B.J. Stuck, B.B. Kahn, AMP-kinase regulates food intake by responding to hormonal and nutrient signals in the hypothalamus, Nature. 428 (2004) 569. doi:org/10.1038/nature02440. 
611 [51] F.P.K. Thomas M. Loftus, Donna E. Jaworsky, Gojeb L. Frehywot, Craig A. Townsend, Gabriele V. Ronnett, M. Daniel Lane, Reduced Food Intake and Body Weight in Mice Treated with Fatty Acid Synthase Inhibitors, Science (80-. ). 288 (2000) 2379-2382. doi:10.1126/science.288.5475.2379.

[52] D.S. Paula Mera, Joan Francesc Mir, Gemma Fabriàs, Josefina Casas, Ana S. H. Costa, Maria Ida Malandrino, José-Antonio Fernández-López, Xavier Remesar, Su Gao, Shigeru Chohnan, Maria Sol Rodríguez-Peña, Harald Petry, Guillermina Asins, Fausto G. Hegardt, Lau, Long-Term Increased Carnitine Palmitoyltransferase 1A Expression in Ventromedial Hypotalamus Causes Hyperphagia and Alters the Hypothalamic Lipidomic Profile, PLoS One. (2004). doi:10.1371/journal.pone.0097195.

[53] R. Nogueiras, P. Wiedmer, D. Perez-Tilve, C. Veyrat-Durebex, J.M. Keogh, G.M. Sutton, P.T. Pfluger, T.R. Castaneda, S. Neschen, S.M. Hofmann, P.N. Howles, D.A. Morgan, S.C. Benoit, I. Szanto, B. Schrott, A. Schürmann, H.G. Joost, C. Hammond, D.Y. Hui, S.C. Woods, K. Rahmouni, A.A. Butler, I.S. Farooqi, S. O’Rahilly, F. Rohner-Jeanrenaud, M.H. Tschöp, The central melanocortin system directly controls peripheral lipid metabolism, J. Clin. Invest. 117 (2007) 3475-3488. doi:10.1172/JCI31743.

[54] P.D. Raposinho, R.B. White, M.L. Aubert, The melanocortin agonist Melanotan-II reduces the orexigenic and adipogenic effects of neuropeptide Y (NPY) but does not affect the NPYdriven suppressive effects on the gonadotropic and somatotropic axes in the male rat., J. Neuroendocrinol. 15 (2003) 173-81.

[55] J.P. Cavalcanti-de-Albuquerque, M.R. Zimmer, J. Bober, M.O. Dietrich, Rapid shift in substrate utilization driven by hypothalamic Agrp neurons, BioRxiv. (2016). doi:org/10.1101/086348. 
[56] A. Reichenbach, R. Stark, M. Mequinion, R.R.G. Denis, J.F. Goularte, R.E. Clarke, S.H. Lockie, M.B. Lemus, G.M. Kowalski, C.R. Bruce, C. Huang, R.B. Schittenhelm, R.L. Mynatt, B.J. Oldfield, M.J. Watt, S. Luquet, Z.B. Andrews, AgRP Neurons Require Carnitine Acetyltransferase to Regulate Metabolic Flexibility and Peripheral Nutrient Partitioning, Cell Rep. 22 (2018) 1745-1759. doi:10.1016/j.celrep.2018.01.067.

[57] N.J. Rothwell, M.J. Stock, A role for brown adipose tissue in diet-induced thermogenesis, Nature. 281 (1979) 31. doi:org/10.1038/281031a0.

[58] M.D. Marian Apfelbaum, M.D. Jean Bostsarron, M.D. Dimitri Lacatis, Effect of caloric restriction and excessive caloric intake on energy expenditure, Am. J. Clin. Nutr. 24 (1971) $1405-1409$.

[59] X. Yang, H.-B. Ruan, Neuronal Control of Adaptive Thermogenesis, Front. Endocrinol. (Lausanne). 6 (2015) 1-9. doi:10.3389/fendo.2015.00149.

[60] Y.H. Yasuda T, Masaki T, Kakuma T, Hypothalamic melanocortin system regulates sympathetic nerve activity in brown adipose tissue, Exp Biol Med. 229(3):235 (2004).

[61] H. Bin Ruan, M.O. Dietrich, Z.W. Liu, M.R. Zimmer, M.D. Li, J.P. Singh, K. Zhang, R. Yin, J. Wu, T.L. Horvath, X. Yang, O-GlcNAc transferase enables AgRP neurons to suppress browning of white fat, Cell. 159 (2014) 306-317. doi:10.1016/j.cell.2014.09.010.

[62] C.S. Wu, O.Y.N. Bongmba, J. Yue, J.H. Lee, L. Lin, K. Saito, G. Pradhan, D.P. Li, H.L. Pan, A. Xu, S. Guo, Y. Xu, Y. Sun, Suppression of GHS-R in AgRP neurons mitigates dietinduced obesity by activating thermogenesis, Int. J. Mol. Sci. 18 (2017). doi:10.3390/ijms 18040832.

[63] G.J. Morton, D.E. Cummings, D.G. Baskin, G.S. Barsh, M.W. Schwartz, Central nervous system control of food intake and body weight, Nature. 443 (2006) 289. 
doi:org/10.1038/nature05026.

[64] J.W. Sohn, Network of hypothalamic neurons that control appetite, BMB Rep. 48 (2015) 229-233. doi:10.5483/BMBRep.2015.48.4.272.

[65] S.M. Sternson, Let them eat fat, Nature. 477 (2011) 166. doi:org/10.1038/477166a.

[66] R.D. Cone, Anatomy and regulation of the central melanocortin system, Nat. Neurosci. 8 (2005) 571. doi:org/10.1038/nn1455.

[67] R.M. Leibowitz SF, Roossin P, Chronic norepinephrine injection into the hypothalamic paraventricular nucleus produces hyperphagia and increased body weight in the rat., Pharmacol Biochem Behav. 21(5):801- (1984).

[68] Y. Aponte, D. Atasoy, S.M. Sternson, AGRP neurons are sufficient to orchestrate feeding behavior rapidly and without training, Nat. Neurosci. 14 (2011) 351. doi:org/10.1038/nn.2739.

[69] J.J. Warren, D. Blanchette, D. V Dawson, A. Teresa, K.R. Phipps, D. Starr, D.R. Drake, HHS Public Access, 44 (2017) 319-335. doi:10.1111/cdoe.12200.Factors.

[70] K. Tan, Z.A. Knight, J.M. Friedman, Ablation of AgRP neurons impairs adaption to restricted feeding, Mol. Metab. 3 (2014) 694-704. doi:10.1016/j.molmet.2014.07.002.

[71] R.D.P. Serge Luquet, Francisco A. Perez, Thomas S. Hnasko, NPY/AgRP Neurons Are Essential for Feeding in Adult Mice but Can Be Ablated in Neonates, Science (80-. ). 310 (2005) 683-685. doi:10.1126/science.1115524.

[72] J.C. Erickson, K.E. Clegg, R.D. Palmiter, Sensitivity to leptin and susceptibility to seizures of mice lacking neuropeptide Y, Nature. 381 (1996) 415. doi:org/10.1038/381415a0.

[73] S. Qian, H. Chen, D. Weingarth, E. Myrna, D.E. Novi, X. Guan, H. Yu, Y. Feng, E. Frazier, A. Chen, E. Ramon, L.P. Shearman, S. Gopal-truter, D.J. Macneil, L.H.T. Van Der Ploeg, J. 

Protein nor Neuropeptide Y Is Critically Required for the Regulation of Energy Homeostasis in Mice, Society. 22 (2002) 5027-5035. doi:10.1128/MCB.22.14.5027.

[74] Q. Wu, M.P. Boyle, R.D. Palmiter, Loss of GABAergic Signaling by AgRP Neurons to the Parabrachial Nucleus Leads to Starvation, Cell. 137 (2009) 1225-1234. doi:10.1016/j.cell.2009.04.022.

[75] Joel K. Elmquist Roberto Coppari Nina Balthasar Masumi Ichinose Bradford B. Lowell, Identifying hypothalamic pathways controlling food intake, body weight, and glucose homeostasis, J. Comp. Neurol. 493 (n.d.) 63-71. doi:org/10.1002/cne.20786.

[76] D. Atasoy, J.N. Betley, H.H. Su, S.M. Sternson, Deconstruction of a neural circuit for hunger, Nature. 488 (2012) 172. doi:org/10.1038/nature11270.

[77] P. J. Verhulst A. Lintermans S. Janssen D. Loeckx U. Himmelreich J. Buyse J. Tack I. Depoortere, GPR39, a Receptor of the Ghrelin Receptor Family, Plays a Role in the Regulation of Glucose Homeostasis in a Mouse Model of Early Onset Diet-Induced Obesity, J. Neuroendocrinol. 23 (2011) 490-500. doi:10.1111/j.1365-28262011.02132.x.

[78] Y. Sun, P. Wang, H. Zheng, R.G. Smith, Ghrelin stimulation of growth hormone release and appetite is mediated through the growth hormone secretagogue receptor., Proc. Natl. Acad. Sci. U. S. A. 101 (2004) 4679-84. doi:10.1073/pnas.0305930101.

[79] D. Chen, S., Chen, H., Zhou, J., Pradhan, G., Sun, Y., Pan, H. and Li, Ghrelin receptors mediate ghrelin-induced excitation of agouti-related protein/neuropeptide $\mathrm{Y}$ but not proopiomelanocortin neurons, J. Neurochem. 4 (2017). doi:org/10.1111/jnc.14080.

[80] M. Goto, H. Arima, M. Watanabe, M. Hayashi, R. Banno, I. Sato, H. Nagasaki, Y. Oiso, Ghrelin increases neuropeptide $\mathrm{Y}$ and agouti-related peptide gene expression in the arcuate 
nucleus in rat hypothalamic organotypic cultures, Endocrinology. 147 (2006) 5102-5109. doi:10.1210/en.2006-0104.

[81] R. Lage, C. Diéguez, A. Vidal-Puig, M. López, AMPK: a metabolic gauge regulating wholebody energy homeostasis, Trends Mol. Med. 14 (2008) 539-549. doi:10.1016/j.molmed.2008.09.007.

[82] Z.B. Andrews, Z.-W. Liu, N. Walllingford, D.M. Erion, E. Borok, J.M. Friedman, M.H. Tschöp, M. Shanabrough, G. Cline, G.I. Shulman, A. Coppola, X.-B. Gao, T.L. Horvath, S. Diano, UCP2 mediates ghrelin's action on NPY/AgRP neurons by lowering free radicals, Nature. 454 (2008) 846. doi:org/10.1038/nature07181.

[83] M.O. Dietrich, C. Antunes, G. Geliang, Z. Liu, Y. Nie, A.W. Xu, D.O. Souza, Q. Gao, S. Diano, B. Gao, T.L. Horvath, Agrp neurons mediate Sirt's action on the melanocortin system and energy balace: roles for Sirt1 in neuronal firing and synaptic plasticity, 30 (2011) 1181511825. doi:10.1523/JNEUROSCI.2234-10.2010.Agrp.

[84] D.A. Velásquez, G. Martínez, A. Romero, M.J. Vázquez, K.D. Boit, I.G. Dopeso-Reyes, M. López, A. Vidal, R. Nogueiras, C. Diéguez, The Central Sirtuin 1/p53 Pathway Is Essential for the Orexigenic Action of Ghrelin, Diabetes. 60 (2011) 1177 LP-1185. doi:org/10.2337/db10-0802.

[85] R. Nogueiras, M. López, R. Lage, D. Perez-Tilve, P. Pfluger, H. Mendieta-Zerón, M. Sakkou, P. Wiedmer, S.C. Benoit, R. Datta, J.Z. Dong, M. Culler, M. Sleeman, A. Vidal-Puig, T. Horvath, M. Treier, C. Diéguez, M.H. Tschöp, Bsx, a novel hypothalamic factor linking feeding with locomotor activity, is regulated by energy availability, Endocrinology. 149 (2008) 3009-3015. doi:10.1210/en.2007-1684.

[86] A. Brunet, L.B. Sweeney, J.F. Sturgill, K.F. Chua, P.L. Greer, Y. Lin, H. Tran, S.E. Ross, R. 
Mostoslavsky, H.Y. Cohen, L.S. Hu, H.-L. Cheng, M.P. Jedrychowski, S.P. Gygi, D.A. Sinclair, F.W. Alt, M.E. Greenberg, Stress-Dependent Regulation of FOXO Transcription Factors by the SIRT1 Deacetylase, Science (80-. ). 303 (2004) 2011 LP-2015. doi:10.1126/science.1094647.

[87] P.S. Pardo, J.S. Mohamed, M.A. Lopez, A.M. Boriek, Induction of Sirt1 by mechanical stretch of skeletal muscle through the early response factor EGR1 triggers an antioxidative response, J. Biol. Chem. 286 (2011) 2559-2566. doi:10.1074/jbc.M110.149153.

[88] M.O. Dietrich, J. Bober, J.G. Ferreira, L.A. Tellez, Y.S. Mineur, D.O. Souza, X.-B. Gao, M.R. Picciotto, I. Araújo, Z.-W. Liu, T.L. Horvath, AgRP neurons regulate development of dopamine neuronal plasticity and nonfood-associated behaviors, Nat. Neurosci. 15 (2012) 1108. doi:org/10.1038/nn.3147.

[89] M. Tang-Christensen, N. Vrang, S. Ortmann, M. Bidlingmaier, T.L. Horvath, M. Tschöp, Central administration of ghrelin and agouti-related protein (83-132) increases food intake and decreases spontaneous locomotor activity in rats, Endocrinology. 145 (2004) 4645-4652. doi:10.1210/en.2004-0529.

[90] A. Lira, M. Zhou, N. Castanon, M.S. Ansorge, J.A. Gordon, J.H. Francis, M. Bradley-Moore, J. Lira, M.D. Underwood, V. Arango, H.F. Kung, M.A. Hofer, R. Hen, J.A. Gingrich, Altered depression-related behaviors and functional changes in the dorsal raphe nucleus of serotonin transporter-deficient mice, Biol. Psychiatry. 54 (2003) 960-971. doi:10.1016/S00063223(03)00696-6.

[91] M.O. Dietrich, M.R. Zimmer, J. Bober, T.L. Horvath, Hypothalamic Agrp Neurons Drive Stereotypic Behaviors beyond Feeding, Cell. 160 (2015) 1222-1232. doi:10.1016/j.cell.2015.02.024. 
[92] A. Sahay, K.N. Scobie, A.S. Hill, C.M. O’Carroll, M.A. Kheirbek, N.S. Burghardt, A.A. Fenton, A. Dranovsky, R. Hen, Increasing adult hippocampal neurogenesis is sufficient to improve pattern separation, Nature. 472 (2011) 466. doi:org/10.1038/nature09817.

[93] L. Paeger, I. Karakasilioti, J. Altmüller, P. Frommolt, J. Brüning, P. Kloppenburg, Antagonistic modulation of NPY/AgRP and POMC neurons in the arcuate nucleus by noradrenalin, Elife. 6 (2017) 1-18. doi:10.7554/eLife.25770.

[94] K.E. Claflin, J.A. Sandgren, A.M. Lambertz, B.J. Weidemann, N.K. Littlejohn, C.M.L. Burnett, N.A. Pearson, D.A. Morgan, K.N. Gibson-corley, K. Rahmouni, J.L. Grobe, Angiotensin AT 1A receptors on leptin receptor - expressing cells control resting metabolism, 127 (2017) 1-11. doi:10.1172/JCI88641.

[95] K. Nakajima, Z. Cui, C. Li, J. Meister, Y. Cui, O. Fu, A.S. Smith, S. Jain, B.B. Lowell, M.J. Krashes, J. Wess, Gs-coupled GPCR signalling in AgRP neurons triggers sustained increase in food intake, Nat. Commun. 7 (2016) 10268. doi:org/10.1038/ncomms10268.

[96] J.N. Betley, S. Xu, Z.F.H. Cao, R. Gong, C.J. Magnus, Y. Yu, S.M. Sternson, Neurons for hunger and thirst transmit a negative-valence teaching signal, Nature. 521 (2015) 180. http://dx.doi.org/10.1038/nature14416.

[97] D. Atasoy, S.M. Sternson, Chemogenetic Tools for Causal Cellular and Neuronal Biology, Physiol. Rev. 98 (2017) 391-418. doi:10.1152/physrev.00009.2017.

[98] Y. Anraku, H. Kuwahara, Y. Fukusato, A. Mizoguchi, T. Ishii, K. Nitta, Y. Matsumoto, K. Toh, K. Miyata, S. Uchida, K. Nishina, K. Osada, K. Itaka, N. Nishiyama, H. Mizusawa, T. Yamasoba, T. Yokota, K. Kataoka, Glycaemic control boosts glucosylated nanocarrier crossing the BBB into the brain, Nat. Commun. 8 (2017) 1001. doi:10.1038/s41467-01700952-3. 
[99] L. Yang, Y. Qi, Y. Yang, Astrocytes Control Food Intake by Inhibiting AGRP Neuron Activity via Adenosine A1 Receptors, Cell Rep. 11 (2015) 798-807. doi:10.1016/j.celrep.2015.04.002.

[100] B. Liu, Tiemin \& Kong, Dong \& Shah, Bhavik \& Ye, Chian \& Koda, Shuichi \& Saunders, Arpiar \& Ding, Jun \& Yang, Zongfang \& L Sabatini, Bernardo \& B Lowell, Fasting Activation of AgRP Neurons Requires NMDA Receptors and Involves Spinogenesis and Increased Excitatory Tone, Neuron. 73. 511-22 (2012). doi:10.1016/j.neuron.2011.11.027.

[101] A.H. Shibata M., Banno R., Sugiyama M., Tominaga T., Onoue T., Tsunekawa T., Azuma Y., Hagiwara D., Lu W., Ito Y., Goto M., Suga H., Sugimura Y., Oiso Y., AgRP NeuronSpecific Deletion of Glucocorticoid Receptor Leads to Increased Energy Expenditure and Decreased Body Weight in Female Mice on a High-Fat Diet, Endocrinology. 157 (2016) 1457-1466. doi:org/10.1210/en.2015-1430.

[102] D.O. and C.B. Andrew C. Shin, Nika Filatova, Claudia Lindtner, Tiffany Chi, Seta Degann, Insulin receptor signaling in $\mathrm{POMC}$, but not $\mathrm{AgRP}$, neurons controls adipose tissue insulin action, Diabetes. 66 (2017) 1560 LP-1571. doi:10.2337/db16-1238.

[103] O.K. Egan, M.A. Inglis, G.M. Anderson, Leptin Signaling in AgRP Neurons Modulates Puberty Onset and Adult Fertility in Mice, J. Neurosci. 37 (2017) 3875 LP-3886. doi:10.1523/JNEUROSCI.3138-16.2017.

[104] Y. Kuperman, M. Weiss, J. Dine, K. Staikin, O. Golani, A. Ramot, T. Nahum, C. Kühne, Y. Shemesh, W. Wurst, A. Harmelin, J.M. Deussing, M. Eder, A. Chen, CRFR1 in AgRP Neurons Modulates Sympathetic Nervous System Activity to Adapt to Cold Stress and Fasting, Cell Metab. 23 (2016) 1185-1199. doi:10.1016/j.cmet.2016.04.017.

[105] S.M. Steculorum, L. Paeger, S. Bremser, N. Evers, Y. Hinze, M. Idzko, P. Kloppenburg, J.C. 
Brüning, Hypothalamic UDP Increases in Obesity and Promotes Feeding via P2Y6Dependent Activation of AgRP Neurons, Cell. 162 (2015) 1404-1417. doi:10.1016/j.cell.2015.08.032.

798

799

800

801

802

803

804

805

806

807

808

809

[106] J. Wu, C. Zhu, L. Yang, Z. Wang, L. Wang, S. Wang, P. Gao, Y. Zhang, Q. Jiang, X. Zhu, G. Shu, N-Oleoylglycine-Induced Hyperphagia Is Associated with the Activation of AgoutiRelated Protein (AgRP) Neuron by Cannabinoid Receptor Type 1 (CB1R), J. Agric. Food Chem. 65 (2017) 1051-1057. doi:10.1021/acs.jafc.6b05281.

[107] J. Xu, A.M. Bernstein, A. Wong, X.-H. Lu, S. Khoja, X.W. Yang, D.L. Davies, P. Micevych, M. V Sofroniew, B.S. Khakh, P2X4 Receptor Reporter Mice: Sparse Brain Expression and Feeding-Related Presynaptic Facilitation in the Arcuate Nucleus, J. Neurosci. 36 (2016) 8902 LP-8920. doi:10.1523/JNEUROSCI.1496-16.2016.

[108] H. Ren, J.R. Cook, N. Kon, D. Accili, Gpr17 in AgRP Neurons Regulates Feeding and Sensitivity to Insulin and Leptin, Diabetes. 64 (2015) 3670 LP-3679. doi:10.2337/db15-0390. 
812 Figure 1: Melanocortin system. AgRP/NPY and POMC/CART neurons are located at the base of

813 the hypothalamus in close proximity to fenestrated capillaries. POMC neurons exert an anorexigenic

814 function and increase energy expenditure through the expression of the post-transcriptional product

815 of the POMC gene, including $\alpha$-melanocyte-stimulating hormone $(\alpha-\mathrm{MSH}), \beta-\mathrm{MSH}, \mathrm{\gamma}-\mathrm{MSH}$ that 816 binds to the melanocortin receptor (MCR), an anorexigenic target. NPY/AgRP neurons increase food 817 intake and decrease energy expenditure through the release of neuropeptide Y (NPY), $\gamma$ - amino818 butyric acid (GABA), and agouti-related protein (AgRP). NPY act through NPY1R and NPY5R, 819 while AgRP antagonize $\alpha-\mathrm{MSH}$ action and GABA is an inhibitory neurotransmitter that exerts 820 orexigenic action through GABAergic-mediated inhibition of POMC neurons.

Figure 2: Glucose and insulin pathways'connection between the CNS and peripheral system..1)

Meal consumption increases glucose levels, which depolarize POMC neurons due to the increase in the ATP/ADP ratio that closes the KATP channel. 2) In AgRP neurons, the increase in glucose level causes AKT phosphorylation that activates neuronal nitric oxide synthase (nNOS) and produces nitric oxide (NO). NO binds to soluble guanylyl cyclase (sGC) increasing cyclic guanosine monophosphate (cGMP) levels. cGMP activates protein kinase GII (PKGII) that phosphorylates the cystic fibrosis transmembrane conductance regulator (CFTR), increasing conductance to the chloride channel and hyperpolarizing the neuron. 3) The insulin produced as a result of an increase in glucose level 830 inactivates AgRP neurons as a feedback mechanism. Insulin acts on AgRP neurons through insulin 831 receptor (IR). Insulin receptor substrate (IRS) proteins bind to phosphorylated residues on the IR to 832 activate phosphoinositide 3 kinase (PI3K) that produces phosphatidylinositol 3 phosphate (PIP3) from 
phosphatidylinositol 2 phosphate (PIP2). PIP3 activates KATP, resulting in hyperpolarization and decreasing the firing rate. Phosphoinositide-dependent kinase 1 (PDK1) binds to PIP3 and activates AKT, which enters the nucleus and leads to the exclusion of the forkhead box O (FOXO) 1, which decreases AgRP transcription. 4) The inhibition of AgRP neurons increases the expression of hepatic IL-6 through liver innervation. IL-6 activates Janus kinase/signal transducers and activators of the transcription (Jack-STAT) pathway that inhibits the expression of glucose-6-phosphatase (G6Pase), thereby suppressing hepatic gluconeogenesis. The insulin signaling pathway has also been described in POMC neurons, but the exclusion of FOXO1 from the nucleus promotes POMC transcriptional activation.

Figure 3: Ghrelin signaling pathway in AgRP neurons. Ghrelin activates the growth hormone secretagogue receptor 1a (GHSR1a), a G couple receptor that interacts with Gq protein. The G alpha subunit recruits phospholipase $\mathrm{C}$ (PLCß) that produces inosito-1,4,5-triphosphate (IP3), which increases the $\mathrm{Ca}^{++}$level and interacts with calmodulin $(\mathrm{CaM})$ to activate $\mathrm{CaM}$-dependent protein kinase kinases (CaMKK). This enzyme phosphorylates AMPK, which phosphorylates acetyl-CoA carboxylase (ACC). ACC activation causes a reduction in malonyl-CoA and disinhibition of carnitine palmitoyl transferase 1 (CPT1). The CPT1A enzyme increases long chain fatty acid (LCFA) transport into mitochondria for oxidation. Increased fatty-acid oxidation results in an increase of reactive oxygen species (ROS) and subsequent uncoupling protein-2 (UCP2) activity, which helps to buffer

852 intracellular ROS. UCP2 acts as a critical mitochondrial biogenic signal that further enhances the 853 bioenergetic capacity of AgRP neurons and ensures efficient transcription of AgRP and NPY genes 854 through the transcriptional factors BSX with FoxO1 and pCREB. The Sirtuin 1/p53 pathway is 855 essential for the orexigenic action of ghrelin and is involved in AMPK activation. 


\begin{tabular}{|c|c|c|c|c|}
\hline Receptor & Type & Ligand & Function & Reference \\
\hline $\begin{array}{l}\text { Adenosine A1 receptors } \\
\text { (A1R) }\end{array}$ & $\begin{array}{l}\text { G protein-coupled } \\
\text { receptors }\end{array}$ & Adenosine & $\begin{array}{l}\text { Astrocytes inhibit AgRP } \\
\text { neuron activity via A1R }\end{array}$ & [99] \\
\hline $\begin{array}{l}\text { Angiotensin } \\
\text { AT1A receptors }\end{array}$ & $\begin{array}{l}\text { G protein-coupled } \\
\text { receptors }\end{array}$ & Angiotensin & $\begin{array}{l}\text { Contribute to the control of } \\
\text { resting metabolic rate (RMR) }\end{array}$ & [94] \\
\hline $\begin{array}{l}\text { NMDA receptors } \\
\text { (NMDARs) }\end{array}$ & $\begin{array}{l}\text { Ionotropic glutamate } \\
\text { receptors }\end{array}$ & Glutamate & $\begin{array}{l}\text { Control of body weight, body } \\
\text { fat, food intake, glucose } \\
\text { homeostasis. }\end{array}$ & {$[20,100]$} \\
\hline Glucocorticoid receptors & Nuclear receptor & Glucocorticoids & $\begin{array}{l}\text { Control of body weight and } \\
\text { energy expenditure }\end{array}$ & [101] \\
\hline Insulin receptor & Tyrosine kinase receptors & Insulin & $\begin{array}{l}\text { Control of body weight and } \\
\text { food intake }\end{array}$ & {$[35,102]$} \\
\hline Leptin receptor LepR & Type I cytokine receptor & Leptin & Control of food intake & [103] \\
\hline$\alpha 2 \mathrm{~A}$ - adrenergic receptors & $\begin{array}{l}\text { G protein-coupled } \\
\text { receptors }\end{array}$ & Noradrenalin & Feeding and food intake & [93] \\
\hline $\begin{array}{l}\text { Corticotropin-releasing } \\
\text { factor receptor type } 1 \\
\text { (CRFR1) }\end{array}$ & $\begin{array}{l}\text { G protein-coupled } \\
\text { receptors }\end{array}$ & $\begin{array}{l}\text { Corticotropin-releasing } \\
\text { hormone }(\mathrm{CRH})\end{array}$ & $\begin{array}{l}\text { Protects the organism from } \\
\text { hypothermia and } \\
\text { hypoglycemia }\end{array}$ & [104] \\
\hline $\begin{array}{l}\text { Growth hormone } \\
\text { secretagogue receptor } \\
\text { (GHS-R1A) }\end{array}$ & $\begin{array}{l}\text { G protein-coupled } \\
\text { receptors }\end{array}$ & Ghrelin & Food intake & [80] \\
\hline $\begin{array}{l}\text { Pyrimidinergic receptor } \\
\text { P2Y6 }\end{array}$ & $\begin{array}{l}\text { G protein-coupled } \\
\text { receptors }\end{array}$ & Uridine-diphosphate & $\begin{array}{l}\text { Food intake and systemic } \\
\text { insulin sensitivity in obesity }\end{array}$ & {$[41,105]$} \\
\hline $\begin{array}{l}\text { Cannabinoid receptor type } \\
1 \text { (CB1R) }\end{array}$ & $\begin{array}{l}\text { G protein-coupled } \\
\text { receptors }\end{array}$ & N-oleoylglycine (OLGly) & Food intake & [106] \\
\hline Purinergic receptor $\mathbf{P} 2 \mathrm{X} 4$ & ATP-gated cation channels & ATP & Food intake & [107] \\
\hline
\end{tabular}




\begin{tabular}{|c|c|c|c|c|}
\hline $\begin{array}{l}\text { Uracil nucleotide/cysteinyl } \\
\text { leukotriene receptor } \\
\text { GPR17 }\end{array}$ & $\begin{array}{l}\text { G protein-coupled } \\
\text { receptors }\end{array}$ & $\begin{array}{l}\text { Purinergic and cysteinyl- } \\
\text { leukotriene ligands } \\
\text { Unknown endogenous ligand }\end{array}$ & $\begin{array}{l}\text { Energy balance and glucose } \\
\text { homeostasis }\end{array}$ & [108] \\
\hline $\begin{array}{l}\text { Polyunsaturated fatty acid } \\
\text { (PUFA) receptors GPR40 }\end{array}$ & $\begin{array}{l}\text { G protein-coupled } \\
\text { receptors }\end{array}$ & Polyunsaturated fatty acid & Body weight mass regulation & [44] \\
\hline
\end{tabular}


Figure 1

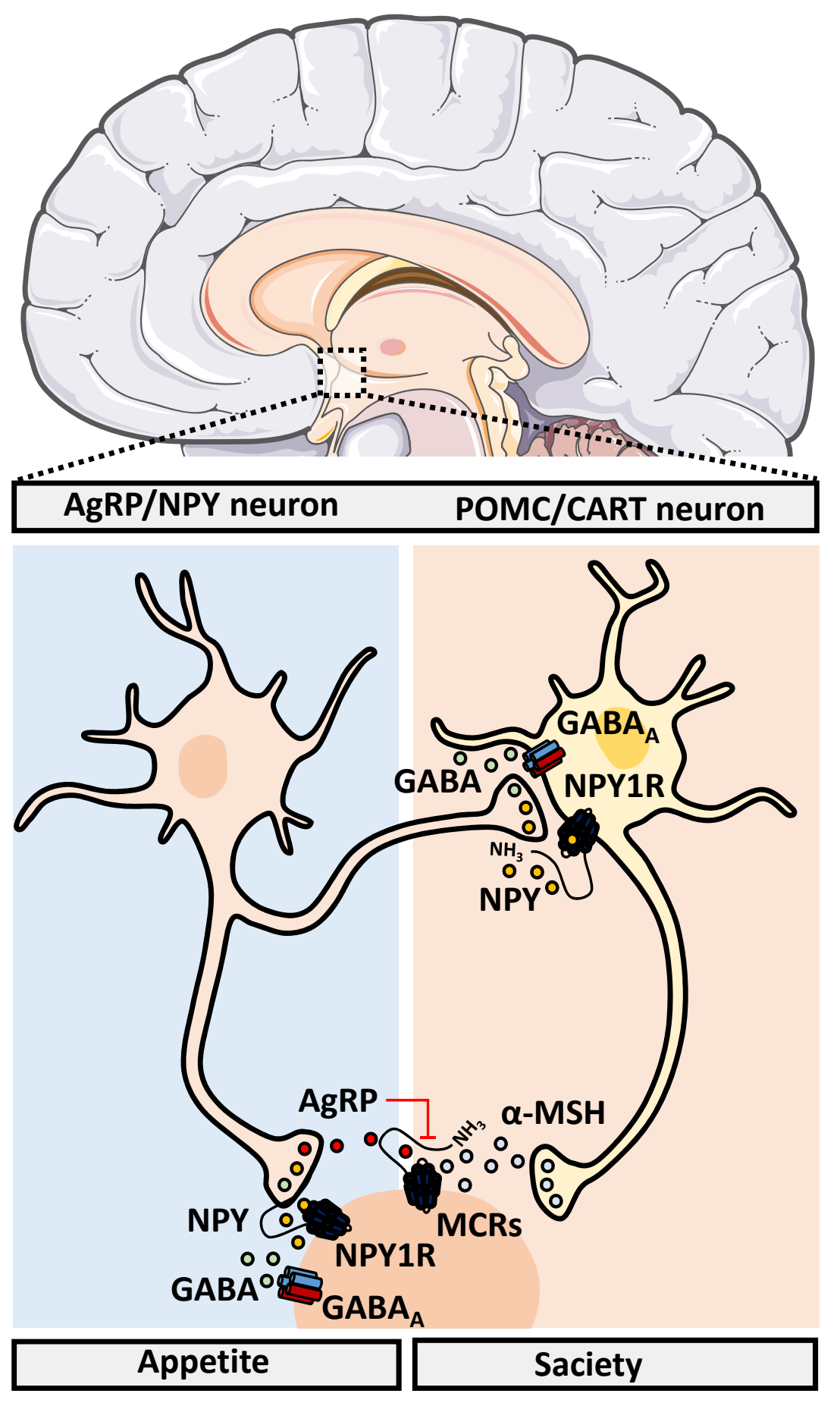




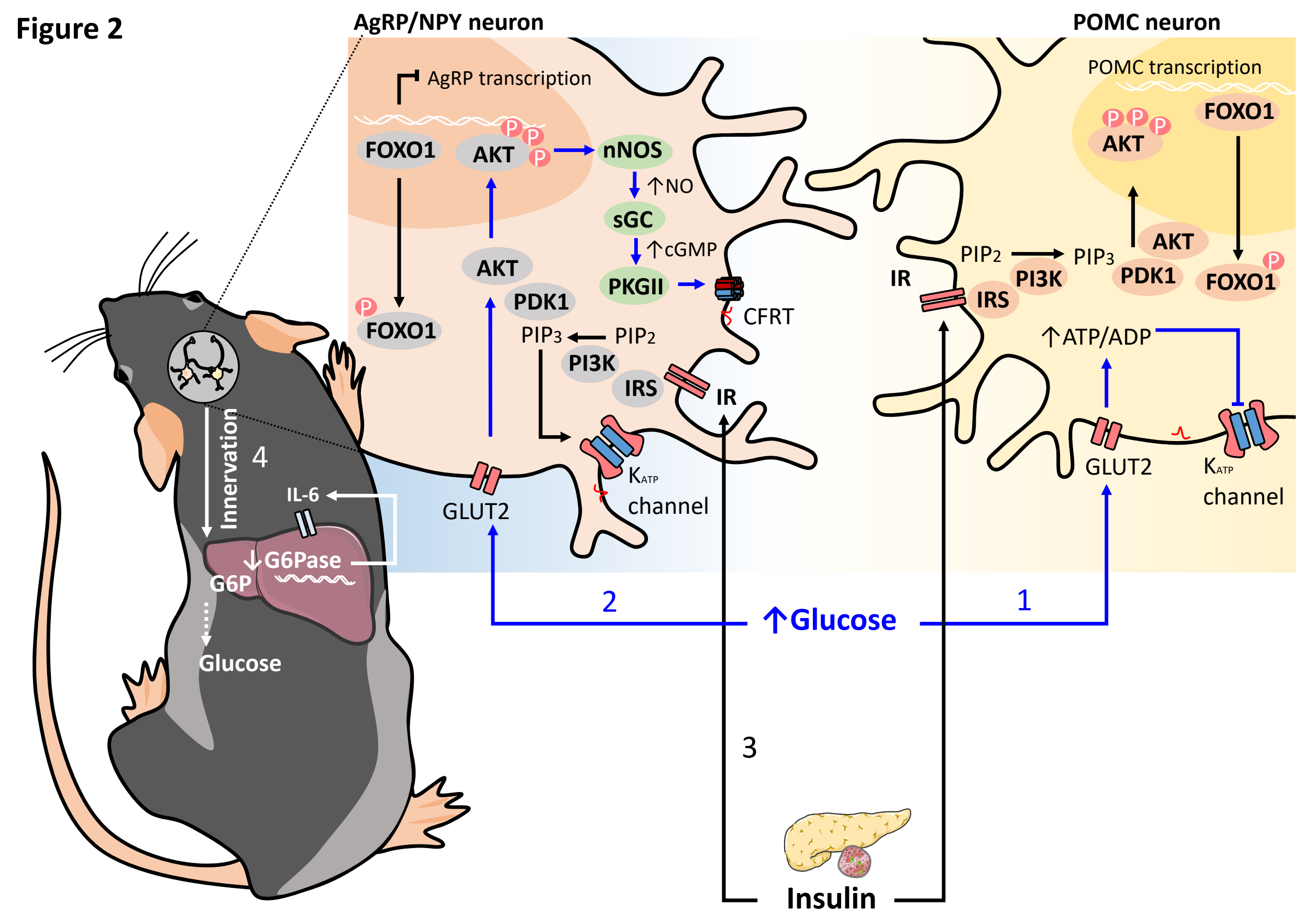


Figure 3

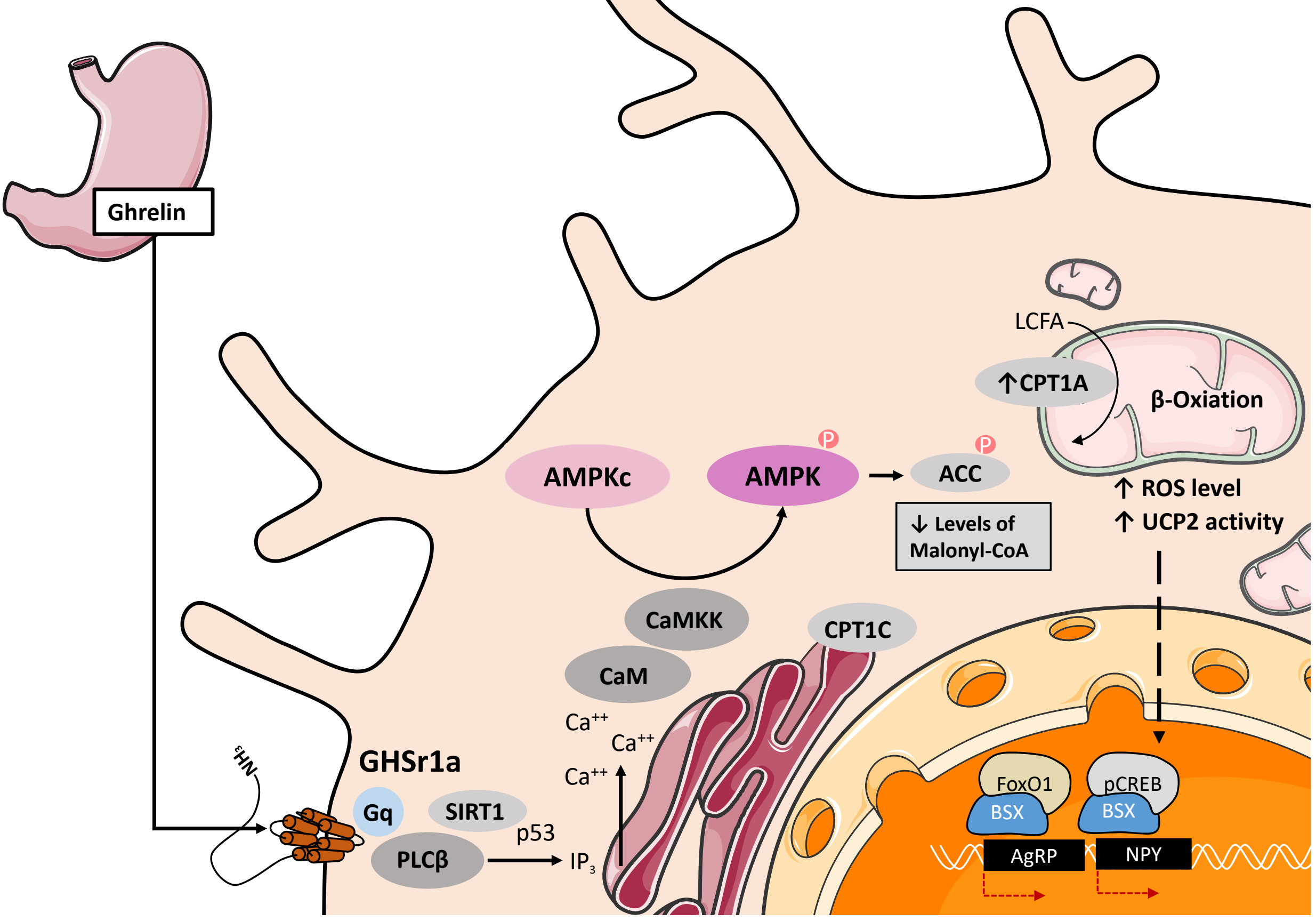

